\title{
WORKSHOP PROGRAM EFFORT OF COMMUNITY LEARNING CENTER (PKBM) IN PREVENTING TEENAGER PROMISCUITY \\ (Case Study in PKBM Bina Mandiri Cipageran Cimahi)
}

\author{
Nunu Mahmud Firdaus \\ IKIP Siliwangi \\ mahmudfirdaus@gmail.com
}

\begin{abstract}
PKBM is an institution engaged in education and is formed by the community for people. PKBM is still under the supervision and guidance of the National Education Office. PKBM can be either in village or sub-district level. However, the establishment of this institution has not been so many yet, because the community assumption related to the need of PKBM is still low. Through this study, the researcher wants to reveal the important role of PLS as in this case is PKBM to become the vehicle of education for the community. In the current era of globalization free social relations increasingly widespread and certainly harm the dignity and dignity of the nation. So the function of the PLS as a substitute, the complement of formal education needs to be strengthened so that the education department is really able to form a complete Indonesian man. Challenges in the globalization era are very large towards the world of education, the development of science and technology changes the social life of Indonesian people, especially foreign cultures threaten the civilization of Indonesia nation. In forming complete Indonesian people, education determine direction of the next generation, through formal education, but it is not entirely successful without the supports of nonformal school or. As the negative result, promiscuity among people or even students is inevitable. In related to this problem, the researcher wants to prove that non-formal education gives effects to the development of Indonesian people generation. The researcher does comparison to the regions which have PKBM institutions in order to provide a clear picture. This study uses qualitative method to see the clear picture of PKBM effort in assessing the outcome of training program on the distribution of talents and interest of adolescents in preventing promiscuity, with the population being sampled as many as 6 people taken from studying citizens. From the results of this research, the role of PKBM training program makes teenagers social relationship become better and more beneficial. PKBM provides a lot of educational support to the community and also becomes a forum for youth and young women. It can be concluded that PKBM can prevent the teenagers from promiscuity, therefore, it is expected that PKBM is established in every village, so that formal education is equipped by nonformal Education because it gives a positive impact on the behavior of the younger generation.
\end{abstract}

Keywords: PKBM efforts, workshop program, promiscuity

\section{A. INTRODUCTION}

In the current globalization era, challenges for the world of education are increasingly heavy due to unlimited information and teenagers social life are very vulnerable to the behavior of deviation against life norms of Indonesian people. Youth generation 
becomes victims affected from the entry of negative foreign cultures. To defend such impact of globalization, formal education should be more introspective to pay attention to the generation of the nation from the danger of promiscuity that can damage the civilization of the Indonesian nation, but if not supported by non-formal and informal education, adolescents often become victims of promiscuity, the community education through PKBM moves apart from the learning of this institution also moves in the field of training which can accommodate the talent and also fill the time to channel talent and can discuss with the people learn especially for those who drop out of school.

From the explanation above, the researcher wants to know the extent to which PKBM training program can prevent teenager's promiscuity in society by collecting information of data and theory put forward by expert. The writer wants to trace the result of education and training from PKBM, especially in this case is prevention of behavioral deviation, from existing that PKBM Training can channel the aspirations of the community from the age of children, adolescence to adulthood. The objects studied by the authors are the studying citizens in adolescents who grow toward maturation. From 20 populations, the writer took 5 samples for the interview, a PKBM manager is also a source of information needed in this study. The writer is looking for information related to environmental challenges, PKBM training programs, and teenager's daily social life.

In the life of society, there is a hope of creating a safe and comfortable life; parents provide education to their children and there exists a prosperous and happy life; teenagers are aware of the norms that apply virtuous and reliable in the future; the youth generation of both boys and girls are excited to build advanced society. This situation is not easy to achieve because of the challenges and obstacles of today's modern contemporaries, teenagers in their development prefer their own way of life regardless of the consequences they generate such as free sex, including drugs, harsh and irreverent words that ultimately lead to crime. These phenomena make the writer curious to know the extent to which PKBM provides an important role in preventing teenage promiscuity, through its training programs. Formal and non formal education must be easily followed by the learners because of how much science must be owned by the Indonesian people to avoid degradation of morals. Mohammad Hatta has said that science is an orderly knowledge of the legal work causally in the same characteristic problems, as well as according to their visible position from the outside or from within. The need for non-formal school is also expected to be an important study by the current government.

\section{RESEARCH FOCUS}

1. Can PKBM training program prevent teenager promiscuity?

2. Can PKBM training program be of interest to the studying participants among teenagers?

\section{RESEARCH OBJECTIVES}

1. To find out the extent to which PKBM training program can teenager promiscuity.

2. To find out the extent to which PKBM training program can be of interest to the studying participants among teenagers. 


\section{SIGNIFICANCE OF RESEARCH}

1. Theoretically

a. To discover new and evolving facts from previous Non-formal education scientific studies.

b. An attempt to find theoretical concepts related to educational programs in building the nation of Indonesia

2. Practical Usefulness

a. To provide information to the reader and government about the importance of off-school education

b. A practical work on problem solving solutions for teen age children

\section{B. LITERATURE REVIEW}

\section{The Concept of Non-formal Education}

Non-formal education is education that is organized outside the school whether institutionalized or non-open educational activities are more open, unbound, and noncentralized, the out-of-school education program can be the development of a school program, and can be an education equivalent to the school's education (Oong Komar, 2006).

Coombs (1976) in defining non-formal education stated that "Non-formal education is distinguished form formal and informal education and is defined broadly as any organized educational activity outside the established formal system -whether cooperating, separately or as an important feature for some broader activity that is intended to serve identifiable learning clienteles and learning objectives. "

\section{Community Learning Activity Center (PKBM)}

PKBM philosophy is briefly from, by and for society. This means that PKBM is a Community Based Institution. From society as a philosophy, it means that PKBM establishment must always be an initiative of the society itself that comes from an awareness of the importance of improving the quality of life through a transformational and learning process. This initiative can be generated by a process of socializing the importance of PKBM and other matters concerning PKBM to some members or local community leaders by the government or by other parties outside the community. In the case of establishment of PKBM, the role of government or other parties outside the community is just process of socialization, motivation, stimulation and training to introduce PKBM as a whole and open perspective and insight and steps that can be done in forming PKBM and in further development. This socialization process should not take over the founding initiative that must come purely from the awareness, willingness and commitment of the members of the community itself. This is very important in order to maintain the development of PKBM in a healthy future which determines the independence and sustainability of the PKBM.

\section{Pergaulan Bebas (Promiscuity/Free Sex)}

According to KBBI (Big Indonesian Dictionary), pergaulan means to live befriend or hang out with others in community. Bebas is loose and unobstructed, so that we can talk, move, and do things freely, without being bound by rules. In English, pergaulan bebas is translated into free sex/promiscuity. Promiscuity is a behavior of friendship 
that is not bound by the rules and social norms prevailing in society, as in this case, it is an Eastern custom which upholds the norms of decency. The term of promiscuity in Indonesia is widely used in Indonesia since mid 60's. At that time, the era of globalization made the western culture easily enter into Indonesia. Especially information from the world of entertainment, such as movies and music, spread through print and electronic media. All sorts of promiscuity are:

1. Free sex, committing acts of adultery out of wedlock, no safety, and swapping pairs.

2. Student fights either with a shootout or use of sharp weapon.

3. Smoking and drug abuse.

4. Living on the streets and dropping out of school

5. Motorcycle gang and others.

\section{RESEARCH METHODS}

\section{Research Methods}

The method of this study is qualitative method. This is based on the consideration of the depth of the results of research related to the meaning of the generalization, the researcher maximizes the observation and interviews, both with regard to the relevance of the contents of the question with the study, as well as related to the accuracy of the respondents.

Sugiyono (2016) stated that qualitative research method is a research method based on post-positivism philosophy, is used to examine the natural object, which is as a key instrument, the sampling of data sources conducted by purposive and snowball. Technique of data collection with triangulation (composite) more qualitative research results emphasizes the meaning of generalization.

In the field implementation, the researcher merges with the situation under study, this is done considering that human behavior is influenced by the "setting" in which the situation occurs, so that human behavior cannot be understood without understanding the frame in which humans

Interfere with the thought and its actions. The research is conducted through taking the steps based on the following stages:
a. Identifying Problems
b. Study Literatures
c. Develop a Research Design
d. Make observation and interview guidelines
e. Analyzing
f. Writing Research Reports.
g. Research sites
h. Population and Sample

\section{RESULTS AND DISCUSSION}

\section{General Description}

a. Profile of PKBM Bina Mandiri

Community Learning Activity Center (PKBM) is a place of community learning activities in order to provide educational services and skills to the community in having 
knowledge and attitude of self-control in following development of the time so it can be useful in facing the sharing of social turmoil that occurred.

From the interviews conducted with 5 correspondents, they are very happy to learn in PKBM Bina Mandiri, and it is shown by their participation to follow the program so that they can avoid the promiscuity which is very vulnerable to adolescence if not balanced with education both formal and non-formal such as this PKBM. In interviews, the researchers get a clear picture that non-formal education has a role in the field of education that is not less important than formal education. So, this shows that the program age of PKBM can prevent younger generation falling into promiscuity because it is more binding like family who has each other.

\section{Discussion}

This study aims to know the role of PKBM program in preventing free association, the researcher takes 5 people as sample as the studying participants who are still in the age of teenager ranging from 16-20 years old. The assumption of this research shows important role of non-formal education institution in society for promiscuity issues. Community Learning Center (PKBM) can be a gathering place for young adolescent of both boys and girls; parents can pay attention to their children. Naddler (1982) in formulating training significances answers the question: what problem can training solve? But with this research can be found that the process of youth empowerment as conducted by PKBM Srikandi indicates that the manager is able to develop various potentials related to the ecology of the surrounding community, thereby developing the capacity of community life on an ongoing basis (Ardiwinata \& Mulyono, 2018).

This research is still far from perfect so that the researcher plans to trace the role of offschool education in preventing deviation behavior. So the result can be a deep study and consideration of the importance of the institution of non-formal education in Indonesia and the hope of the researcher to the government that can give more attention to nonformal education, so that the collaboration of formal and non-formal education is able to succeed in creating a generation ready to face the turmoil of globalization by supporting high noble values of Indonesia.

\section{E. CONCLUSIONS AND SUGGESTIONS}

1. Conclusions

The following researchers draw conclusions from this study:

a. Community Learning Activities Center Program contributes to prevent promiscuity. It is illustrated that the junior high school students who participate in PKBM activities are far from free sex because PKBM can provide a foundation for the alarming social pressure.

b. PKBM is in demand by the studying participants, the atmosphere of a friendly institution, does not make awkward in learning; so, grows a sense of ownership of the learners.

\section{Suggestions}

This suggestion is submitted by the researcher to the following parties: 
a. To teenagers, they should follow the program of outdoor education because at this time the need for education is not enough just with formal education, in order to avoid the act of deviation.

b. To the government, they should pay more attention to non-formal Education and they are expected to give support so that each village can establish PKBM institution because it is very important in supporting the goals of National education.

\section{REFERENCE}

Ardiwinata, J.S. dan Mulyono, D. 2018. COMMUNITY EDUCATION IN THE DEVELOPMENT OF THE COMMUNITY. Jurnal Empowerment Vol. 7 (1), hal 20-25

Aslichati, Lilis. (2011). Kematangan Sosial dan Masyarakat Madani,Prosiding Seminar Jakarta. Fisip UT.

Coombs, P.H. (1976). Non formal education: Myths, Realities and Opporunities. Comparative Education Review. Vol 20 No. 3

Depdiknas RI, (2005), Kamus Besar Bahasa Indonesia, Balai Pustaka, Jakarta

Komar, Oong, (2006), Filsafat Pendidikan Nonformal, Grafika Bandung

Marzuki, Saleh 2010 Pendidikan Nonformal. PT Remaja Rosdakarya

Nadler, L. 1982. Designing Training Programs: The Critical Events Model. Sidney: Addison Wesley Publising Company.

Sugiyono, (2016) Metode Penelitian Pendidikan: (Pendekatan Kuantitatif Kualitatif, dan $R \& D)$. Penerbit Alfabeta Bandung

https://visiuniversal.blogspot.co.id/2014/02/pusat-kegiatan-belajar-masyarakatpkbm.html 